\title{
BIG BANG LOCALISM AND GYPSIES AND TRAVELERS
}

ANDREW RYDER ${ }^{l}$

\begin{abstract}
The paper explores how the UK planning system has impacted on Gypsies and Travelers and is partly based upon evidence and conclusions made by the Panel Review of Coalition Government Policy on Gypsies and Travellers which was particularly interested in Coalition Government localist policy.

There are differing interpretations of what 'localism' is but one adherent of localism has described the brand as espoused by a section of Conservatives as 'big bang localism' (Jenkins, 2004). A dogma of radical decentralisation which some would argue has permeated the Coalition Government. As is evidenced in the paper the Coalition's localist policies could have a profound effect on Gypsy and Traveler site provision and race relations. However, localism is not a new phenomena it is a policy which has been applied to Gypsy and Traveler site provision in the past and has alternated with more centralised measures which could be described as 'statist'.
\end{abstract}

KEYwOrDs social inclusion, localism, equality, minority rights, race and ethnicity

\section{INTRODUCTION}

Gypsies originally descended from India and arrived in the UK in the fifteenth century (Fraser, 1995). In the UK they prefer to be termed Gypsies, Romany Gypsies or Romanichel. Irish Travelers, like Gypsies, are classified as an ethnic group and have travelled and resided in the UK for centuries (Ryder and Greenfields, 2010). New Travelers are not an ethnic group but have taken up travelling traditions (Clark and Greenfields, 2006). The

\footnotetext{
1 Andrew Ryder is a fellow at Bristol University, associate fellow with the Third Sector Research Centre (Birmingham University) and visiting professor at the Corvinus University Budapest, e-mail: andrew.ryder@uni-corvinus.hu; the paper was supported by TÁMOP-4.2.1./ B-09/1/ KMR-2010-0005.
} 
provision of Gypsy and Traveler sites (pitches where Gypsies and Travelers can station their caravans) is a major social policy challenge in the UK, which to date successive governments have failed to remedy.

One fifth of the caravan dwelling Gypsy and Traveler population in the UK do not have an authorized place to live, instead occupying unauthorized developments or encampments (Cemlyn et al, 2010). It has been estimated that only one square mile of land is needed to address the present shortfall of approximately 5000 pitches

(EHRC, 2009). However, despite the relative small scale of the problem it has proven to be one of the biggest challenges facing local and national politicians, where a lack of political will in the face of localized opposition to site development has often stalled progress. This paper draws the conclusion that the localist policies being advocated by the UK Coalition Government hold the potential to exacerbate existing shortages and further strain community relations. To emphasize these dangers it is worth considering a statement by the Gypsy Council which gives an insight into what it describes as the "dark side of localism“:

"Whenever proposals come up local residents and parish councils object vociferously. The levels of abuse and objection to development for our people are hard to understand but almost universal. Language and attitudes that have been unacceptable since the 1970s to black people, Jews and gays are commonplace in regard to Travellers, particularly when it is proposed that they should live within a community. This is why the planning system is at the heart of the inequalities from which Travellers suffer. Councillors are put under huge local political pressures to oppose sites "(The Gypsy Council, 2010).

The paper will explore how the planning system has impacted on Gypsies and Travelers and is partly based upon evidence and conclusions made by the Panel Review of Coalition Government Policy on Gypsies and Travellers. The Panel Review was organized by the Travellers Aid Trust and was funded by the Joseph Rowntree Charitable Trust. The author of this paper acted as the lead researcher to the Panel Review, where a panel of politicians from the main parties together with academic experts took evidence in the UK parliament over a two day period from a range of participants including:

- Gypsies and Travelers

- Local authorities and Parish Councils

- Service providers

- The police 
The Panel Review adopted a deliberative approach by including a wide range of stakeholders, who have not always agreed or held common positions on this issue, in the hope of finding consensus and common agreement. It was hoped that the formation of a consensus might facilitate influence on the outcome of the Localism Bill progressing through parliament through the Panel Review report 'A Big or Divided Society?'. A large number of the participants welcomed the extension of local democracy but expressed the view that for a sensitive and controversial issue like Traveler site provision that a form of central duty is needed to overcome local opposition. This paper sets out that case.

\section{THE CONTEXT}

Following the 2010 election and the emergence of a hung parliament the Conservatives and Liberal Democrats formed a Coalition Government. A joint plan of governmental policy and action was set out in the document (The Coalition: our program for government, 2010). Of relevance to the planning framework and Gypsies and Travelers, the report states:

"The Government believes that it is time for a fundamental shift of power from Westminster to people. We will promote decentralisation and democratic engagement, and we will end the era of top-down government by giving new powers to local councils, communities, neighbourhoods and individuals" (Cabinet Office, 2010, 11).

In July 2010, Eric Pickles, the Secretary of State at the Department for Communities and Local Government (CLG), announced that he was using his power under section 79(6) of the Local Democracy, Economic Development and Construction Act 2009 to revoke Regional Strategies in order "to put greater power in the hands of local people rather than regional bodies " (Ryder et al, 2011). Traveler sites as well as housing had formed part of the Regional Strategy targets; the abolition of these could thus have a major impact on site provision.

\section{BIG BANG LOCALISM AND BEFORE}

There are differing interpretations of what 'localism' is but one adherent of localism has described the brand as espoused by a section of Conservatives as 'big bang localism' (Jenkins, 2004). A dogma of radical decentralization 
which some would argue has permeated the Coalition Government. As will be evidenced, the Coalition's localist policies could have a profound effect on Gypsy and Traveler site provision and race relations. However, localism is not a new phenomenon; it is a policy which has been applied to Gypsy and Traveler site provision in the past and has alternated with more centralized measures which could be described as 'statist'.

Diagram 1 - Localist and Statist Approaches to Gypsies and Travelers

- Duty placed on councils to provide Traveller sites (council sites on which rents were paid)

Statist

- Duty scrapped - councils asked to help Gypsies and

1994

Localist Travellers to buy their own land and develop own sites.

- Obligation on councils to assess Gypsy and Traveller

2006 accommodation needs. If councils failed to reach targets the Government could intervene.

Statist

- Obligation to meet pitch targets abolished - all councils told to determine their own pitch numbers - no government intervention if target not met

2011

- Greater power for Parish Councils in planning

- Referenda

A purely localist approach existed prior to 1968 as no central policy existed on site provision apart from measures which placed greater restrictions on where Gypsies and Travelers could reside and locate sites. Thus it was very much up to local authorities whether they chose to help support Traveler site development, and many chose not to (Hawes and Perez, 1996). Consequently, there was a growing shortage of sites and stopping places leading to an increasing number of unauthorized encampments and a corresponding strain in relations between Gypsies and Travelers and the settled communities in housing. The Labour MP Norman Dodds had argued for some form of central directive on site provision since the 1950s but had largely been ignored but by the late 1960s the Labour Government concluded that such a measure combined with enforcement measures might be the solution to growing community tensions (Acton, 1974). The Government indicated to the Liberal MP Eric Lubbock that it would support his proposal for such a duty which he hoped to steer through parliament as a private members' bill. The resulting piece of legislation (the1968 Caravan Sites Act) placed a duty on certain local 
authorities to provide sites and by the date of its abolition in 1994 had created a network of 350 sites which were largely council-owned and managed and on which residents paid rents (Richardson and Ryder, 2009).

One of the factors that contributed to this expansion of site provision was that there was political consensus in the 1970s and 80s on the need for a statutory duty on councils to provide sites which meant there was governmental consistency which ensured the policy was not derailed through rapid policy changes every time there was a change of government. Although the Act had created a relatively large number of sites, in fact many more than later measures were to deliver, the Act contained some of the traits of an over centralized statist policy in the sense that it took little account of the aspirations of Gypsies and Travelers and how and where they wanted to live. Sites often occupied marginal space, being located near canals, rail lines, busy roads, industrial areas and even municipal rubbish dumps, in spaces where Gypsy and Traveler settlements were unlikely to provoke opposition from the settled community (Clark and Greenfields, 2006). Furthermore, sites were governed by what residents deemed to be authoritarian management regimes where they did not enjoy the same rights concerning tenure as other residents of social housing, which led to some Gypsies and Travelers referring to these sites as 'reservations' (Johnson et al, 2010).

In 1994 the duty to provide sites was abolished and in its place Department of the Environment Circular 1/94 was introduced in which local authorities were encouraged, but not obliged, to assist Gypsies and Travelers to develop sites and endorsed the private provision of sites by Gypsies and Travelers themselves. However in this very localist approach many councils chose not to support planned site provision and the number of unauthorized encampments continued to grow as did tensions in community relations. The Labour Government concluded that Circular 1/94 was not addressing the growing shortage of Gypsy and Traveler sites. In 2003 the Labour Government initiated a policy review on Gypsy and Traveler site provision which culminated in the Office of the Deputy Prime Minister (ODPM) Circular 1/2006. This placed an obligation on local authorities to carry out a Gypsy Traveler Accommodation Needs Assessment (GTAA) which would identify the need for sites and feed into regional targets set by Regional Spatial Strategies (now known as Regional Strategies following the Local Democracy, Economic Development and Construction Act 2009). Where local authorities failed in their new responsibilities, the Secretary of State had powers of direction to make councils identify land for site development if they had failed to do so by the deadline set of 2011. Although containing a central and statist obligation to provide sites, this only came into action where at a local and regional level 
councils had failed to identify land for the requisite number of pitches allocated to them through the benchmarking of local assessments and allocation of a target (which sometimes involved an element of redistribution) by regional assemblies (Ryder et al, 2011). Hence, the policy could be described as a hybrid of local, regional and centralized approaches which placed a strong emphasis on consultation and which accorded Gypsies and Travelers (unlike the 1968 Act) some say as to the location and design of sites (CLG, 2007).

In the two years prior to the introduction of Circular $01 / 2006,68 \%$ of appeals relating to Gypsy and Traveler sites were dismissed. In the following two years, $65 \%$ of appeals were granted planning permission (CLG, 2009, 4). Despite some modest progress it has been estimated that at that rate of pitch provision it would take local authorities 18 years to meet the targets specified in relation to permanent pitch requirements set for a 5 year period (Brown and Niner, 2009). The secretary of State, Eric Pickles, has seized upon this fact as a sign that the policy was failing (CLG, 6th July 2010). However, it should be noted that the success of the policy was skewed by the approaching general election; with some councils aware that if the Conservatives won then the policy would be scrapped, it appears they decided to drag their feet on site delivery (Richardson and Ryder, 2009). In fact, Pickles whilst in opposition had encouraged such a process by calling upon Conservative Councils not to comply with New Labour Government directives which fell under his categorization of "nanny state, politically correct or vanity projects." (The Guardian, 2nd July, 2009).

Pickles also argued that the policy created perceptions of 'unfairness' by the general public concerning the outcomes of planning cases by Gypsies and Travelers. A CLG press release (13th April, 2011) said: “... the old planning rules created a perception of special treatment for some groups, undermining the notion of fair play in the planning system and further harming community cohesion." However, research by Panel Review member Dr Jo Richardson into planning appeals before and after the introduction of Circular 1/2006 has noted that the percentage of cases allowed prior to Circular 1/2006 was $40 \%$, rising to a peak of $70 \%$ during the established phase of implementation of Circular 1/2006) but that there has been a reduction in the number of appeals allowed since the Secretary of State's announcement on the replacement of the Circular and the revocation of RSs (Richardson, 2011, 8). Richardson notes that there was a perception prior to Circular 1/2006 that Gypsies and Travelers were disadvantaged in the planning system and that, proportionately, more applications for Traveler sites were refused than there were refusals for bricks and mortar planning applications in the wider community. There was hope that Circular 1/2006 would redress the balance and give a more even footing 
to applications for sites (Richardson, 2011, 8). In this sense Circular 1/2006 can be seen as a tool which leveled inequality in the planning system rather than one that created 'unfairness' and one which acted as a tool of 'positive action' which has generally been accepted by the main political parties and the European Union as a legitimate tool to address inequality (European Union, 2009). It is of concern though that the new planning statement is being driven by what are, in fact, unfounded perceptions of unfairness. Previous research has demonstrated that clear and informed public perceptions together with firm and fair leadership and reporting are key factors in ensuring support for site delivery (Richardson, 2006; 2007). The real test of the regional strategies propounded by Labour would have come into play in 2011 when councils were due to reach the deadline set for identifying land and at which point the government could have intervened, but as has been noted, the policy was repealed before the deadline was reached.

The Localism Bill which at the time of writing is progressing through parliament is expected to become law in the later part of 2011. The policy will abolish Regional Strategies and targets for homes (including housing and Traveler sites) and give parish councils (council bodies based on small geographic areas such as villages) and neighborhood forums a greater say in the planning process. Local communities will also be given the power to trigger local referenda on issues and decisions by councils that they are concerned about. The fear has been expressed that these powers could present a 'nimby' (not in my back yard) charter which will frustrate and block developments which do not meet with popular support, Gypsy and Traveler site provision is likely to be prominent amongst projects that will attract strong opposition in which opponents can take advantage of localist measures to frustrate such development (Ryder et al, 2011). Although local authorities are being encouraged to continue to assess local Gypsy and Traveler needs, that process is not to be prescriptive and unlike the previous policy will not contain benchmarking by regional assemblies to correct assessments which have under-estimated need. Steve Staines of the Traveller Law Reform Project reported to the Panel Review that a survey of 34 councils (excluding London) indicated a pitch loss of 360 when compared to the targets that had previously been set by Regional Assemblies. Where councils were proceeding with some site development it was overwhelmingly based on figures established by their own Gypsy and Traveller Accommodation Needs Assessments (GTAA) which in many cases identified lower levels of need than that set by regional assemblies (Ryder et al, 2011). Furthermore where councils do not achieve the targets which they can set for themselves, under a localist agenda there will be no prospect of government intervention. 
A number of participants in the Panel Review felt that site provision as with affordable housing had come to a virtual standstill. Sections of the building industry have already expressed concern at this situation. At the CLG Select Committee inquiry into the abolition of Regional Strategies, David Orr, chief executive of the National Housing Federation (which represents housing associations) said the decision to get rid of the targets was "a hasty and damaging move, which has already seen plans for over 180,000 homes scrapped" (BBC News, 10, 11, 2010). This could be attributed to the lack of detailed policy proposals in the present policy vacuum whilst the new planning circular is being developed and legislation passed through parliament. However, the reluctance of many councils to act on the issue of site provision is a key factor in development coming to a standstill. In a survey of the East, South East and South West of England, the Irish Traveler Movement in Britain (ITMB) found a significant drop in planned site provision when compared to targets set under the previous regional strategy.

The ITMB study focused on three regions in England and had returns from 100 of the 152 local authorities (66\%). The response rate varied: $91 \%$ in the East of England, $68 \%$ in the South West and 47\% in the South East. The now abolished Regional Strategies had allocated pitch targets to every local authority; the study found that $63(63 \%)$ of the 100 local authorities who responded had targets for additional residential pitches, while $37(37 \%)$ did not. $74 \%$ of East of England councils had residential pitch targets, $80 \%$ in the South West, but only $34 \%$ in the South East. This constitutes a drop of 52 per cent in councils' targets for additional residential pitches from the 2,919 that had been identified as needed under the previous policy. Only one (1\%) of the authorities contacted saw the Localism and Decentralization Bill as likely to make planning for Gypsies and Travelers easier while 40 (40\%) expected it to make it more difficult. $13(13 \%)$ thought it would make no difference, 25 $(25 \%)$ weren't sure and $15(15 \%)$ said they weren't sure but made comments indicating it would be more difficult. $40 \%$ of respondents expressed concerns about increased local opposition to development for Travelers under the localist planning regime (ITMB, 2011).

The Coalition Government believes that the New Homes Bonus once introduced will reward local authorities that deliver housing as well as public and private Traveler sites. Councils will receive council tax matching funding for six years. New local authority pitches will attract additional money in the same way as affordable housing. Rather than meeting targets, the Government argues that local authorities will instead have real incentives to provide Traveler sites and communities will see the benefits of development (Ryder et al, 2011). However, there is a strong fear that this plan to incentivize construction will 
not overcome what will be intense opposition to site construction (Ryder et al, 2011). Roy Donson, Regional Planning \& Strategic Land Director, Barratt Developments Plc has said of the New Homes Bonus:

"That is a completely novel approach, and we cannot put our hands on our hearts and be certain it works. I am absolutely certain in my own mind that Ministers are sincere about their desire for more housing and that they believe the New Homes Bonus-type structure will work, but it is quite a high-risk strategy because nothing like that has ever been tried before. I think there must be a plan B, and probably that plan is that if the New Homes Bonus as currently outlined - we do not have much detail on it at the moment-does not do the trick something must be added to it to make it work and we must keep at it until it does"(CLG uncorrected oral evidence, 8th November, 2010). An in depth analysis of how a localist agenda failed to deliver sufficient new sites in 1994 may give important indications as to why the Coalition Government's localist policies may inevitably fail.

\section{LOCALISM IN FOCUS}

Diagram 2 - How Commonly Held Beliefs stalled Site Provision Post Circular 1/94 and Contributed to Community Tensions

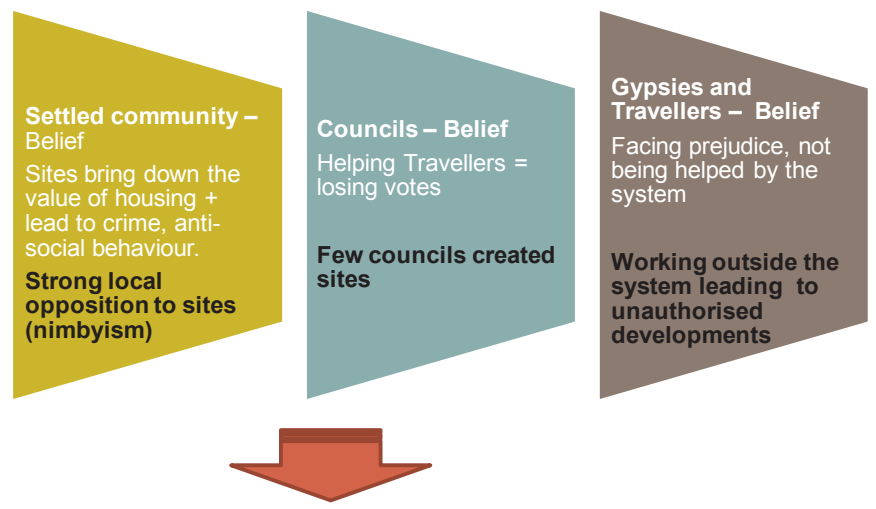

Every One Lost

Sites were in inappropriate places

High cost of enforcement 


\section{Community relations strained}

During the late 1980s and early 1990s a public furor developed over a group known as New Travelers, a non ethnic group which took up a nomadic lifestyle which grew out of the festival movement (Clark and Greenfields, 2006). This led to a public furor, often fueled by an intemperate media, in which New Travelers became 'folk devils' (Richardson, 2006). This resentment crystallized into the decision by the Conservative Government of John Major to restrict unauthorized (i.e. roadside) encampments in the Criminal Justice and Public Order Act of 1994 but also to repeal the duty on local authorities to provide sites and in effect privatize site provision through Planning Circular 1/94 (See above). Action which much to the chagrin of ethnic Gypsies and Travelers fell upon the entirety of the Gypsy and Traveler community (Hawes and Perez, 1996).

In order to reveal the pitfalls of a localist approach in terms of increasing site provision and contributing to community cohesion the paper will look in depth at the localism policy which was introduced through Planning Circular 1/94. The lack of compulsion meant few local authorities initiated serious measures to provide sites. Instead, prejudice and fears, mainly articulated through public opposition, made many councils reluctant to help (Richardson, 2007). Councilors were often fearful that support for sites would lead to local electorates punishing them at the ballot box; those who were to some degree sympathetic bemoaned the fact that they were not being compelled to act by a statutory duty as this enabled them to direct the blame at central government and declare they had no choice. Another impediment to local authorities being proactive in increasing site provision was the fear of the 'honeypot' effect, a belief that if they acted and neighboring local authorities did not then their authority would attract larger numbers of Gypsies and Travelers who would become an accommodation and service 'burden' (ODPM, 2004). Clearly such fears are more pronounced under a localist planning regime as opposed to one where all authorities are compelled to act in unison.

In rare cases where councils did act or where Travelers decided to initiate an unauthorized development (going outside of the planning system by moving onto land and then submitting a retrospective planning application) opposition could be vociferous. Local residents' would invariably form action groups and large public meetings would be held - one such meeting in Crawley attracted 1000 opponents (Richardson and Ryder, 2009). The language and behavior of such campaigning was highly derogatory and in some cases statements made by the public impinged race relations codes and left a spirit of disharmony and ill will to Gypsies and Travelers which percolated into every aspect of local community life, including schools, and left a legacy of mutual fear and 
mistrust which lasted for years (Richardson, 2007).

The localist policy of Planning Circular 1/94 left many Gypsies and Travelers feeling that the planning system and local authorities were set against them. The growing shortage of local authority sites following the repeal of the duty, combined with a lack of support from local authorities and trust in them to be fair inevitably led to stark choices for many Gypsies and Travelers. They could either live on the side of the road and be subject to a constant cycle of eviction which was facilitated by new enforcement powers in the Criminal Justice and Public Order Act 1994, or move into housing and face the risk of assimilation (Ryder and Greenfields, 2010). A third choice was to buy land and move on to it and over a period of a few days develop a site and then retrospectively hand in a planning application to the local authority (Richardson 2007). However, such a path was fraught with difficulty. To gain permission to reside on their land Gypsy and Traveler families would need to defend their application in quasi legal planning hearings and even high court actions, while often these applications were bitterly resisted by local authorities and residents. For a minority group often characterized by low levels of formal education such litigation was often highly traumatic to families and also costly, running up large legal bills and being a distraction from economic activities (Ryder and Greenfields, 2010).

For some Gypsies and Travelers their gamble with the planning system ultimately failed and in some cases led to the forcible eviction and demolition of Gypsy and Traveler sites by private bailiff firms contracted by local authorities, scenes which received scant media attention but which were highly emotive for Gypsies and Travelers. The UK Association of Gypsy Women (2009) articulates concerns about forced eviction: "Over the years, heavy machinery has been deployed with no duty of care to the children, sick or elderly on the sites and on occasions the elderly and the sick have been beaten and manhandled as they are evicted. Homes have been destroyed and sometimes, with families still inside. Bailiffs violate health and safety policies of the UK without fear of prosecution". The Committee for the Elimination of Racial Discrimination in its fourth periodic report on the UK expressed concern about the levels of enforcement and forced eviction used against Traveler sites (ECRI, 2010). Media attention instead, largely through the tabloid press, has depicted families living on unauthorized developments as lawbreakers flouting the planning system; sensationalist reporting which culminated in the Sun Newspaper articles entitled 'Stamp on the Camps' which led to Gypsies and Travelers becoming an election issue in the 2005 General Election where opposition Conservative leader Michael Howard unveiled a 7 Point Charter on Gypsies and Travelers which focused on enforcement with no reference to provision and called upon Travelers to 'play by the rules' in the British 
tradition of 'fairness' (Richardson and Ryder, 2009).

The cost to local authorities and the wider community was also great. In 2002 the cost of eviction and enforcement was estimated to be18 million per annum (Clements and Morris, 2002), a cost which may escalate given that one large eviction at the Dale Farm Site in Essex will cost the local authority an estimated 10 million pounds, or 117,000 pounds per family to be evicted (BBC, 11th July, 2011). Localism was also costly to the settled community by the inconvenience caused by unauthorized sites being placed in inappropriate locations, sometimes in locations which could impact negatively on house prices, though such price declines were often a result of publicity and residents in effect talking down their own house prices by voicing their fears about the consequences of a nearby Traveler site development. Hence, it is evident that a wide range of stakeholders including Gypsies and Travelers, the wider community and local authorities suffered to varying degrees under a localist policy. There is a fear that the Coalition Government's localist policies will lead to a return to the failures of localist policies that were established in 1994 (Ryder et al, 2011).

\section{WIN-WIN SITUATIONS}

A long-standing view of campaigners for Traveler law reform is that the drawbacks as outlined above of a localist planning regime for a vulnerable minority can be mitigated through some form of central government intervention. Such a concept has often been supported through the 'win-win' potential of providing more sites. The Gypsy campaigner Len Smith stated that "More sites for Gypsies and Travellers is a win-win situation, not only does it give Gypsies and Travellers a decent home and access to services but it reduces the inconvenience of unauthorized sites for the settled community "(Cited in Ryder et al, 2011). To emphasize this point campaigners placed great store in building up a broad alliance for the return of an obligation to provide sites, which included local authorities and politicians from the main parties and residents affected by unauthorized encampments. This lobbying was one factor which eventually prompted the New Labour Government to act through its regional policies but it could be argued that it failed to convincingly take these arguments to the wider public, hence creating a state of affairs where the Coalition Government can effortlessly remove interventionist policies on this issue.

Increasing local democracy has many merits, but there are many interpretations and forms of localism. Coalition Government policy may merely empower a section of the community who already are vocal and active in community politics. Not just Gypsies and Travelers will be the potential losers under this 
form of localism, a sizeable minority that could be affected are those struggling to get 'affordable housing' (namely low cost home ownership or access to social housing). The privatization of council housing and the marketization of the construction industry as well as a housing bubble which has seen price inflation make home ownership unattainable for a large number of not just low but also middle income families are factors that have contributed to the housing shortage. However, another factor contributing to the shortage has been local authorities and residents, primarily in affluent areas who oppose provision of affordable housing. Opposition which stems from a desire to retain the existing class profile of an area or merely having no interest in affordable housing because of their own well positioned economic status. The New Homes Bonus (see above) may lack the strength to overcome this opposition. An alternative would be to have a duty on local authorities to provide affordable housing which would include Traveler sites/social housing/low cost homes. The merit of this idea is that it could force the hand of reluctant councils. In the past, when campaigners called for the return of a duty to provide sites, opponents would turn around and say "But no such duty exists for housing for the settled community!". Also at public meetings which opposed sites the point was raised that homeless Traveler families had been forced to initiate unauthorized developments, to which local people responded "But we have young couples in this area who cannot afford a home and they are in the same boat!". A duty on affordable housing would overcome these arguments but also unite Gypsies and Travelers with the many people in the wider community who need somewhere to live and could create a powerful lobby and a clearer and more populist 'win-win' policy scenario. It could also be argued that such a large scale affordable housing program would create a stimulus to the construction industry and economy. However, such an idea is unlikely to gain favor in the present political climate in which localism is in vogue with the present government. A prerequisite for change is a realization by the general public that state intervention can be for the greater good and that equality warrants checks and balances in local democracy, which may lead to a state of affairs where a duty to provide affordable housing is one day popularly embraced.

\section{CONCLUSION}

The Coalition Government has embraced localism with a fervor which has led to the Government labeling these reforms 'revolutionary' (CLG, 10th December, 2010). Such localism is not out of character with the political make-up of the right, given the coupling of localism with a process of 
marketization which will see services put out to tender and strategic decisionmaking undermined and potentially vetoed, hence localism appeals to 'rightist' notions of individualism, the free market and laissez faire social policy and a belief that these reforms will be cost cutting, an attractive proposition in an age of deficit reduction. The vacuums that are left are to be filled by forms of nineteenth century philanthropism and volunteerism and welfare strategies based on business models which constitute the 'Big Society', or what could equally be termed the 'small state'. The conclusions drawn in this paper are that Gypsies and Travelers could be further marginalized in this policy framework.

Gypsies and Travelers are 'insular minorities', being systematically disadvantaged and having little bargaining power (Rostas and Ryder, 2012). The fundamental weakness and moral flaw of localism is that the weak and vulnerable in society will be left in some cases to the mercy of local majorities that have little care or regard for unpopular or politically weak minorities or interests. Hence, alongside opposition to Traveler sites, some communities will choose to oppose wind farms, care homes, affordable housing and so forth for a number of 'nimbyist' and self interested or prejudicial reasons. This scenario, which reflects the notion that the views of the majority in a local area should always be of ultimate import, can be questioned on the grounds that it can conflict with the interests of the 'greater good'. A principle which is accepted by many when applied to transport, energy and environmental protection (Parvin, 2011) but not so readily when applied to minority interests, in particular the needs of Gypsies and Travelers. Here local majorities or majorities stirred up by small oligarchies and chorus leaders of parochialism can form a tyranny and driven by prejudices can deny a minority fundamental rights such as a decent place to live and access to services (Fung, 2002). This is a fear noted by the Communities and Local Government Select Committee inquiry into localism "A range of organisations representing the interests of vulnerable, marginalised or minority groups expressed fears that a decentralised system in which 'bureaucratic accountability' mechanisms had been dismantled would leave services for such groups at the mercy of the vagaries of local politics and funding choices made under the pressure of cuts" (CLG, 2011 point 59). There is therefore the potentional for illiberal actions in localism if one accepts that an important part of the liberal tradition is the protection of minority rights. As Parvin notes:

“..the centralisation of decision making power also fulfills another function of liberal democratic political systems - namely the protection of minority groups from the tyranny of the majority...... 
liberal democratic principles may not always be best served by devolving decision making power down to local communities because it is entirely possible that local communities might use this power to enact policies or initiatives that violate liberal principles and make the lives of certain members worse" (Parvin, 2009).

It was to avoid and break the log jam of nimbyist opposition to strategic projects that notions of civic leadership have been accepted in the past, where councilors for example were prepared to face and oppose the views of the majority in the interests of a greater good. In the case of Gypsies and Travelers that has been to achieve a reduction in enforcement costs and better life chances for a vulnerable minority. In one parliamentary debate one MP captured the motivation of such civic leadership in the past:

"I can remember as a child that my father, who was then a senior councillor on Havering council, sought to resolve the deep unhappiness that unregulated and illegal Traveller sites caused in that area. He took the view that it was important to find sites that could be properly managed and where the Gypsy and Traveller families were better able to access education for their children, health care and advice on what were and were not acceptable actions when living in the locality. That was an enlightened view at the time, but we are now some 40 years down the line, and successive Governments have failed to provide a solution that works for the settled communities, who face unacceptable levels of illegal and unauthorised sites. It also fails to deal with the needs of travelling communities and Gypsies “. (Alison Seabeck MP ,7 Dec 2010: Hansard Column 15WH).

Firm and strong civic leadership, not afraid to challenge prejudice or take seemingly unpopular decisions for the greater good has been recognized as a key component in Traveler site delivery (Richardson, 2006). However, in many cases, past and present civic leadership has buckled and backtracked in the face of strong local opposition to sites. Hence, although strong and central safeguards are needed to deliver equality they can only be guaranteed if a process of public persuasion and education can also take place in tandem. The regional strategies attempted this by placing a strong emphasis on dialogue and consultation in site delivery and some notable converts were made in particular at councilor level but this dialogue often failed to percolate down to and inform communities at a grassroots level (Ryder et al, 2011). Such a process may be a long term proposition involving more positive images of 
this minority in the media and curriculum but also for Gypsies and Travelers to be known and to be accepted in communities. This can be a long process, as is evidenced by the experiences of one Gypsy at the Panel Review of Coalition policy. After failing in his first attempt to secure a site through the planning system, Mr. Tom McCready initiated a planning application for the second time, retrospectively. Tom found that the council was initially strongly opposed to his application. Tom noted:

"...that attitude relaxed when the attitude of the local people relaxed. And at the end of the third temporary permission I went and applied again for a permanent permission and there was one person protesting who it turns out is a member of the British National Party.... And a lot of people supported me, a lot of people said we'd like Mr. McCready to stay. So now after 10 years, I got a permanent planning permission. I've got a lot of friends in the village, my children have received an education in the village, medical help, I'm paying the taxes, my children, two of them are working now and paying the taxes. So it's a success story. But at the cost of 10 years of mental anguish to my wife and I. If I had not been able to make a retrospective application, had the inspector not been able to say you have a duty towards this family, that wouldn't have happened, and it would have been an entirely different story" (Ryder, et al, 2011, 25).

However, as indicated by this statement such persuasion and mind changing processes cannot take place in the short term or even before a site is built. In some cases civic leadership may have to force through site development measures in the courageous hope and belief that they are doing the right and humane thing and that with time local populations will accept such need (Richardson, 2007). Part of this process involves accepting elements of positive action but also human rights principles. Where special mechanisms exist on site delivery these should not be viewed as unfair advantages but instead as a form of 'positive action' which is enabling Gypsies and Travelers to catch up, and for the huge inequality of underprovision of sites to be addressed (Richardson, 2011). Such mechanisms should be viewed as part of a minority rights framework where the state recognizes that for minorities to receive protection and equality then special frameworks can be warranted and counted as part of a liberal tradition that values group rights as well as those of the individual and which for proponents of minority rights can entail policies to combat racism and discrimination which can incorporate positive or affirmative action (Kymlicka1995). A model that avoids the pitfalls of the 
oligarchies and tyrannies of localism and centralism may be contained in 'Empowered Participatory Governance' which is both 'bottom up' and 'top down'; through which decentralization can create public buy-in and support and tailoring of policy to meet local needs and circumstances and be informed by expert local knowledge but be combined with a form of centralism which checks parochialism and inequity and ensures marginalized groups' needs and aspirations are taken account of (Fung and Wright, 2001). Empowered Participatory Governance is a model that could be successfully applied to social policy for Gypsy Roma Traveler communities and in a wider context at both a national and European level with those who are the focus of policy being given effective involvement in design and delivery of services and policies that affect their lives.

\section{REFERENCES}

Acton, T. (1974) 'Gypsy politics and social change', London, Routledge; and Kegan Paul

Brown, P. and Niner, P. (2009) Assessing local housing authorities' progress in meeting the accommodation needs of Gypsy and Traveller communities in England. Equality and Human Rights Commission

BBC 10/11/2010 'Eric Pickles housing move unlawful'

BBC 2/8/2011 'Dale Farm travellers camp eviction notices served' http://www. bbc.co.uk/news/uk-politics-11725812 Cabinet Office (2010) The Coalition: our programme for government. London

Cemlyn, S, Greenfields, M, Burnett, S, Matthews, Z and Whitwell, C. (2009) Inequalities experienced by Gypsy and Traveller communities: a review. (Research Report no. 12), London: Equality and Human Rights Commission

Clark, C. and Greenfields, M. (2006) 'Here to Stay: The Gypsies and Travellers of Britain', Hatfield: University of Hertfordshire

Communities and Local Government. (2007) Overview of Gypsies and Travellers: Gypsy and Traveller Accommodation Policy. London: CLG Available at: http:// www.communities.gov.uk/housing/housingmanagementcare/gypsiesandtravellers/

Communities and Local Government (2009) Progress Report on Gypsy and Traveller Policy Communities and Local Government (6th July 2010) 'Eric Pickles puts stop to flawed Regional Strategies'

Communities and Local Government (10th December, 2010) ' Revolutionary new rights for communities will protect and transform local services' Press release

Communities and Local Government Select Committee (2011) Third Report Localism, London: CLG

Communities and Local Government (2011 Press Release) 'Eric Pickles: time for fair play for all on planning' 13th April 2011 CLG 
Communities and Local Government Select Committee (2011) Third Report Localism, London: CLG

Department of the Environment Circular 1/94 - Gypsy Sites and Planning. London. DoE

Equality and Human Rights Commission (2009) Gypsies and Travellers: Simple Solutions for Living Together. London. EHRC

European Commission against Racism and Intolerance (2010) Fourth periodic report on the UK, Strasbourg: ECRI

European Union. (2009) International Perspectives on Positive Action Measures: A Comparative Analysis in the European Union, Canada, The United States and South America

Fraser, A. (1995) The Gypsies: The People's of Europe (2nd Ed). London: Blackwell.

Fung, A and Wright, E, O (2001) 'Deepening Democracy: Innovations in Empowered Participatory Governance' in Politics and Society Vol 29

Fung, A (2002) 'Creating Deliberative Publics: Governance After Devolution and Democratic Centralism' - The Good Society Vol 11 Number 1

Guardian - Hencke, D (2nd July, 2009) 'Tory councils told: 'Say no to Labour' New strategy targets what party calls nanny state and vanity projects'

Gypsy Council - Memorandum (2010 ARSS 55) - Written Submissions to the Communities and Local Government Select Committee Inquiry into the Abolition of Regional Spatial Strategies

Hawes and Perez. (1996) The Gypsy and the State: The Ethnic Cleansing of British Society. Bristol: Policy Press

ITMB (2011) Planning for Gypsies and Travellers: The Impact of Localism - Executive Summary (ITMB, 2011)

Jenkins, S (2004) Big Bang Localism: A Rescue Plan For British Democracy. London, Policy Exchange

Johnson, C, Ryder, A, Willers, M (2010) 'Gypsies and Travellers in the United Kingdom and Security of Tenure', European Roma Rights Centre. Budapest. ERRC

Kymlicka, W (1995) Multicultural Citizenship: A Liberal Theory of Minority Rights. Oxford: Oxford University Press

Office of the Deputy Prime Minister (2004) Select Committee on Office of the Deputy Prime Minister: Housing, Planning, Local Government and the Regions Thirteenth Report. London. ODPM

Office of the Deputy Prime Minister Circular 01/2006 - Planning for Gypsy and Traveller Caravan Sites. London. ODPM

Parvin, P (2009) 'Against Localism: Does Decentralising Power to communities fail minorities?' The Political Quarterly 80 (3) pgs 351-360

Parvin, P (2011) 'Localism and the left' Renewal, 19 (2)

Richardson, J (2007) Contentious Spaces: The Gypsy/Traveller Site Issue: York/ Coventry: JRF/CIH

Richardson, J (2011) 'The Impact of Planning Policy Circular 1/06 on Gypsies and 
Travellers in England' De Montfort University, Leicester

Richardson, J (2006) The Gypsy Debate: can discourse control? Exeter: Imprint Academic

Richardson, J. and Ryder, A. (2009) 'New Labour's policies and their effectiveness for the provision of sites for Gypsies and Travellers in England' in Trehan, C. and Sigona, N. (eds.) 'Contemporary Romani politics: recognition, mobilisation and participation', London, Palgrave Macmillan

Rostas, I and Ryder, A (2012) EU Framework for National Roma Integration Strategies: Insights into Empowerment and Inclusive Policy Development in Ryder, A and Richardson, J (2012) 'Gypsies and Travellers: Accommodation, Empowerment and Inclusion in British Society' (Policy Press)

Ryder, A and Greenfields, M (2010) 'Roads to Success: Routes to Economic and Social Inclusion for Gypsies and Travellers' (A report by the Irish Traveller Movement in Britain funded by Big Lottery Research)

Ryder, A., Acton, T., Alexander, S., Cemlyn, S., van Cleemput, P., Greenfields, M., Richardson, J., and Smith, D. (2011) A Big or Divided Society? Report of the Panel Review into the Impact of the Localism Bill and Coalition Government Policy of Gypsies and Travellers, Kidwelly: Travellers Aid Trust.

UK National Association of Gypsy Women (2009) Annual Report

Willers, M (2011) Planning for Traveller Sites: A Rough Guide to the Consultation on the Coalition Government's Draft Planning Policy Parliamentary Debates and Hearings (Alison Seabeck MP ,7 Dec 2010 : Hansard Column 15WH)

UNCORRECTED TRANSCRIPT OF ORAL EVIDENCE To be published as HC 517-iii

House of Commons Oral Evidence Taken Before the Communities and Local Government Committee Abolition of Regional Spatial Strategies Monday 8 November 2010 - Roy Donson 